\title{
Recent advances in the preconcentration and determination of platinum group metals in environmental and biological samples
}

\author{
KOMENDOVÁ, R.
}

Trends in Analytical Chemistry

2020, vol. 122, January 2020, pp. 1-12

ISSN: 0165-9936

DOI: https://doi.org/10.1016/j.trac.2019.115708

Accepted manuscript

(C) 2020. This manuscript version is made available under the CC-BY-NC-ND 4.0 license (http://creativecommons.org/licenses/by-nc-nd/4.0/), doi: https://doi.org/ 10.1016/j.trac.2019.115708

Final version available from

https://www.sciencedirect.com/science/article/pii/s0165993619304741 


\title{
Recent advances in the preconcentration and determination of platinum group metals in environmental and biological samples
}

\author{
Renata Komendova
}

\begin{tabular}{|c|}
\hline Abbreviations \\
\hline 8-hydroxyquinoline-5-sulfonic acid \\
\hline adsorptive cathodic stripping voltammetry \\
\hline Ajatine ${ }^{\circledR}$ benzyldimethyl(dodecyl)ammonium bromide \\
\hline APDC ammoniumpyrrolidindithiocarbamate \\
\hline aqua regia (HCL: $\left.\mathrm{HNO}_{3} 3: 1\right)$ \\
\hline Bond-Elut $\mathrm{C} 18 \AA$ octadecylmodified silica gel \\
\hline CMDCT bis(carboxylmethyl)dithiocarbamate \\
\hline CNF-PEI cellulose nanofibrils modified with polyethyleneimine \\
\hline 1-hexadecylpyridinium chloride \\
\hline certified reference material \\
\hline hexadecyl(trimethyl)ammonium chloride \\
\hline $\begin{array}{l}\text { DKTS APSG diphenylketone-monothiosemicarbazone modified } \\
\text { silica }\end{array}$ \\
\hline dimethylglyoxime \\
\hline DMG SG dimethylglyoxime on silica \\
\hline DPTH-gel 1,5-bis(di-2-pyridyl)methylene thiocarbohydrazide \\
\hline differential pulse voltammetry \\
\hline ET-AAS electrothermal atomic absorption spectrometry \\
\hline flame atomic absorption spectrometry \\
\hline HMImT 1-hexyl-3-methylimidazole-2-thione \\
\hline ICP-MS inductively coupled plasma mass spectrometry \\
\hline $\begin{array}{l}\text { ICP-OES inductively coupled plasma optical emission spectrome- } \\
\text { try }\end{array}$ \\
\hline ionic liquids \\
\hline LEP-OES liquid electrode plasma optical emission spectrometry \\
\hline $\begin{array}{ll}\text { Metalfix-Chelamin }{ }^{\circledR} & \text { polymeric functionalised resin containing } \\
\text { the tetraethylenepentamine group }\end{array}$ \\
\hline $\begin{array}{ll}\text { MetaSep AnaLig® } & \text { selective sorbent for separation of } \mathrm{Au}, \mathrm{Pd}, \mathrm{Pt} \\
& \text { from complex matrices }\end{array}$ \\
\hline microwave digestion \\
\hline MWCNTs multiwalled carbon nanotubes \\
\hline National institute for environmental studies \\
\hline National institute of standards and technology \\
\hline $\begin{array}{c}\text { PAMAM SG amino-terminated dendrimer-like polyamidoamine } \\
\text { immobilized silica gel }\end{array}$ \\
\hline $\begin{array}{l}\text { PAN-TU-GA polyacrylonitrile sorbent modified with thiourea } \\
\text { and glutaraldehyde }\end{array}$ \\
\hline 4-(2-pyridylazo) resorcinol \\
\hline $\mathrm{PEI} / \mathrm{Al}_{2} \mathrm{O}_{3}$ polyethylenimine modified alumina \\
\hline
\end{tabular}

E-mail address: komendova@fch.vutbr.cz (R. Komendova)

\author{
PSTH 1,5-bis(2-pyridyl)-3-sulfophenyl methylene thiocar- \\ bonohydrazide \\ PSTH-cpg 1,5-bis (2-pyridyl)-3-sulphophenyl methylene thiocar- \\ bonohydrazide immobilized on an aminopropyl-con- \\ trolled pore glass \\ QuadraSil ${ }^{\mathrm{TM}} \mathrm{TA}$ triamine modified silicagel \\ RF-OPT Radio-frequency Oxygen Plasma treatment \\ RTILs room temperature ionic liquids \\ SAX sorbent mesoporous silica microparticles functionalized \\ with quarternary amino groups \\ SBA-15 thiol-functionalized mesoporous silicas synthesized by \\ co-condensation of tetraethoxysilane and mercapto- \\ propyltriethoxysilane \\ Septonex® ( $\alpha$-carbethoxypentadecyl)trimethylammonium bro- \\ mide \\ SRM standard reference material \\ Sterinol ${ }^{\circledR}$ benzyl(dodecyl)dimethylammonium bromide \\ Strata C18-E® octadecylmodified silica gel endcapped \\ Strata SDB-L ${ }^{\circledR}$ styrene divinylbenzene sorbent \\ TTAB trimethyl(tetradecyl)ammonium bromide \\ TU thiourea \\ XAD-4® polystyrene-divinylbenzene resin \\ Zephyramine ${ }^{\circledR}$ benzyldimethyltetradecylammonium chloride
}

\section{Introduction}

All platinum group metals (PGMs) (ruthenium, rhodium, palladium, osmium, iridium and platinum) occur naturally in the Earth's crust at very low concentrations. These metals, and their compounds, are very rare and their contents are in the order of tenths of ng.g-1 rock, with the exception of isolated deposits, where their concentration rises from 1000 to 10,000 times these values. They can be found, in their pure form, dispersed in river placers or bound as arsenides and sulphides in ores containing mainly $\mathrm{Ni}, \mathrm{Cu}$ and $\mathrm{Fe}[1,2]$ Unlike other transition metals, PGMs are often found in their elemental form in natural sources with diffuse character.

PGMs are currently used in many modern technologies and products. Their consumption is steadily increasing (from $90 \mathrm{kt}$ in 2010 to $106 \mathrm{kt}$ in 2015). Their reserves and resources are mainly in South Africa $[2,3]$. They are "critical" metals because the demand for them can be influenced by the reliability of the supply, due to socio-economic reasons, but not in terms of the depletion of natural resources 
[4]. The current topic is the recycling of precious elements from electronic waste and used catalysts [5].

However, the anthropogenic entry of these metals and their compounds into the environment is alarming [6]. PGMs, especially platinum, palladium and rhodium, have become a significant source of the anthropogenic entry of heavy metals into the environment over the last three decades, due to their widespread use in the automotive industry. These elements are the main components of automotive catalytic converters and have a very important and irreplaceable function. They are involved in the elimination of toxic compounds produced by the combustion process. However, these elements are released when the car engine is running and become part of automotive emissions. In particular, the exhaust gas comprises a mixture of carbon monoxide, nitrogen oxides, hydrocarbons, as well as some incomplete combustion products, such as aldehydes, ketones, polycyclic aromatic hydrocarbons or carboxylic acids. PGMs reduce the content of these pollutants to concentration levels that meet the required emission standards. Since these standards are becoming increasingly stringent, the use of PGMs is currently essential. Other efforts have been made to reduce the formation of toxic fumes by engine modification, but catalytic systems have proven to be the most effective.

\section{The fate of PGMs in the environment}

Due to their low reactivity, low solubility and mobility, the natural cycle of these metals is very limited, but it is greatly impaired by the anthropogenic input of higher concentrations from automotive emissions. The emission of these metals and their compounds is greatest in high-density traffic routes and the highest in places with poor dispersion conditions (tunnels, underpasses, etc.). However, this contamination has no local impact. Long-distance transport has been proven in the case of PGMs, especially platinum, confirming the global pollution of the entire planet [7].

A major risk of increasing concentrations of PGMs in individual environmental compartments is the inadequate and incomplete information on their toxicity, their effects on human health (and on individual organisms) and the effect of their bioaccumulation in the environment. The influence of platinum to human health and biological materials has been described in a few studies, e.g. Refs. [8-12], and [13]. Even the World Health Organization (WHO) does not have sufficient information about the behavior of these metals and their compounds in the environment, only partial information about platinum [14] and palladium [15]. The issue of platinum speciation and its impact on biological systems, toxicity and environmental behavior are very important. So far, however, there are very few works dealing with the platinum speciation $[16,17]$. The behavior and fate of rhodium and its compounds in the environment is almost unknown.

Other important sources of these metals in the environment are wastewater oncological treatment facilities $[18,19]$. PGMs, especially platinum compounds, but recently, also palladium [20,21] and rhodium, are in the form of some of their complex compounds potent cytostatics, i.e., antitumor metallopharmaceuticals. However, after an effective therapeutic response in the body, they are subsequently excreted from the patient. Contaminated waste water, which is often inefficiently cleaned in wastewater treatment plants, is becoming a point source of these metal compounds [22]. Their removal is only possible using special techniques [23]. These are present in soluble, bioavailable and biologically very active forms [24]. Very often, their cytostatic properties are accompanied by properties that are strongly toxic to living organisms, with a proven carcinogenic effect and very low biodegradability $[25,26]$.

Therefore, anthropogenic inputs lead to the global contamination of all components of the environment. Priority inputs are car emissions and waste water. However, PGMs and their compounds penetrate into all living and nonliving components. They are found in airborne dust $[27,28]$, road dust [29], soil [29-31], vegetation [32,33], wastewater [23,34], river water [24], aquatic organisms and sediments [35], the bodies of animals at higher levels of the food chain [36] and even in the human body $[37,38]$.

\section{Preconcentration of PGMs}

PGMs, despite the above-mentioned anthropogenic sources, are found in environmental components at very low concentrations. Often, such low concentrations cannot be determined directly, even using the most sensitive analytical techniques with very low detection limits (LOD) and quantification limits (LOQ). These techniques include, in particular, the inductively coupled plasma mass spectrometry (ICP-MS) [2]. Buying and operating these devices is often very expensive, evaluated by comparing the cost of acquisition and the cost of one analysis [39]. Therefore, sorption techniques have often been studied, developed, tested and innovated to enrich low levels of PGMs to reach values that can be measured by more common and less expensive techniques, such as electrothermal atomic absorption spectrometry (ET-AAS), flame atomic absorption spectrometry (F-AAS), inductively coupled plasma optical emission spectrometry (ICP-OES) and liquid electrode plasma optical emission spectrometry (LEP-OES). However, these techniques require the use of a preconcentration step (see comparison of typical limits of detection [40] of the above techniques in Table 1).

The most effective method of concentrating PGMs is the Solid Phase Extraction (SPE) method. There are a number of sorbents, whether conventional, selective or specific, which are used for this purpose. The advantage of this technique is not only that it increases the concentration of selected elements to measurable values, but also their simultaneous separation from the sample matrix, which often interferes with the determination of the analyte [42].

Very important parameters for the testing and selection of suitable sorbents are not only their selectivity, specificity, sorption and elution efficiency, and the possibility of reuse, but also price, market availability, the consumption of chemicals and organic solvents used in the sorption process, the effect of possible interference on the sorption course, usability in analyzing real samples and the amount and type of generated chemical waste. The economic and ecological aspect of the developed method of determining PGMs also plays an important role.

The mechanism of platinum sorption largely depends on the type of sorbent and can take place through various physico-chemical interactions, such as adsorption on the surface of the sorbent, sorption of the analyte in the form of chelate, binding of the resulting ion pair, ion associate, or mechanism of ion exchange [43]. By choosing a suitable sorbent with a high affinity for the analyte, it is possible to achieve an effective sorption with high selectivity. Selective and specific reactions

Table 1

Typical detection limits of PGMs, calculated at $3 \sigma[40,41]$.

\begin{tabular}{llllll}
\hline Element & \multicolumn{2}{l}{ Method/LOD } & & \\
\hline & F-AAS & ET-AAS & ICP-OES & LEP-OES & ICP-MS \\
\hline & $\mu g^{-1}$ & $\mu \mathrm{g} \mathrm{L}^{-1}$ & $\mu \mathrm{g} \mathrm{L}^{-1}$ & $\mu \mathrm{g} \mathrm{L}^{-1}$ & $\mathrm{ng} \mathrm{L}^{-1}$ \\
\hline $\mathrm{Ir}$ & 500 & 4 & 4 & - & $0.01-0.1$ \\
$\mathrm{Os}$ & 100 & - & 5 & - & $0.01-0.1$ \\
$\mathrm{Pd}$ & 10 & 0.5 & 2 & 3 & $0.01-0.1$ \\
$\mathrm{Pt}$ & 75 & 4.5 & 20 & 57 & $0.01-0.1$ \\
$\mathrm{Rh}$ & 3 & 0.4 & 5 & - & $0.01-0.1$ \\
$\mathrm{Ru}$ & 100 & 0.75 & 4 & - & $0.01-0.1$ \\
\hline
\end{tabular}


with selected organic agents, or substances forming agents, can be used.

In the adsorption mechanism, the analyte is bound on the solid phase by van der Waals forces or hydrophobic interactions. These hydrophobic interactions are particularly useful in highly non-polar sorbents. The most common sorbents of this type are silica gel, modified by hydrocarbon chain, or selected organic functional groups. Another large group is polymeric styrene-divinylbenzene copolymer sorbents. Elution, in this case, is carried out with organic solvents such as methanol, ethanol or acetonitrile. However, PGMs are most commonly found in solution in the form of their halogenocomplexes, so direct sorption to this type of sorbent does not take place. The ionic forms of PGMs must react with a suitable organic reagent and the resulting complex is then bound to the sorbent only by hydrophobic interactions, or the sorbent must be modified with the selected organic reagent.

The formation of an analyte chelate with a suitable organic chelating agent that contains a heteroatom in its molecule can be used for selective sorption. Nitrogen heteroatoms (nitro-, amino-, imido- and azo-) and sulfur (most commonly thio-functional groups) have a significant affinity for PGMs. The most important requirements for efficient and highly effective sorption are the selectivity of the agent, the stability of the chelate formed, sufficiently rapid chelate kinetics, the good solubility of the chelate formed and the sufficiently strong binding of the resulting chelate to the sorbent surface [42].

If we modify the non-polar sorbent with an ion-pairing agent, it binds with its non-polar part to the non-polar sorbent by hydrophobic forces. With its polar part, it forms an ion pair with the analyte ions, or complexes, in solution. Typical examples of ion-pairing agents are quaternary ammonium salts and alkyl sulfates.

In ion-exchange sorption, sorbents containing anionic or cationic functional groups are used. These groups may be attached to silica ge or styrene-divinylbenzene copolymer-type sorbents. The ion exchange then occurs between the analyzed solution and the solid sorbent. The ion exchange groups can be strongly or weakly dissociated and the applicability depends on the $\mathrm{pH}$ value. Strongly dissociated groups are useful throughout the $\mathrm{pH}$ range, while the weakly dissociated groups were only useful at a $\mathrm{pH}$ higher than the $\mathrm{pKa}$ (dissociation constant). Strongly cationic exchange groups include sulfone groups and strongly anionic-exchange quaternary ammonium salts. The weak cation exchangers are the carboxyl groups and the weak anion exchangers are ternary amines.

A very interesting issue in the area of preconcentration of PGMs in recent years is the use of microextraction. The reason is to minimize the use of organic reagents and to replace them with more environmentally friendly alternatives. These include ionic liquids, also called 21 st century solvents [44]. Ionic liquids (ILs) are those substances that consist of an organic cation and an inorganic or organic anion and have a melting point below $100 \mathrm{C}$. The most interesting are ionic liquids already at room temperature (RTILs). The main advantages of ILs are zero vapor pressure, thermostability, excellent solvation properties, non-flammability and low toxicity. ILs play a key role in microextraction analytical techniques used to preconcentration of PGMs from environmental and biological samples. 1-Hexyl-3-methylimidazole-2-thione [45] or 1-alkyl-3-methylimidazolium chloride [46] was used as an ionic liquid for microextraction of PGMs.

Significant attention was paid to PGMs in the late 1990s. The reason for this was the introduction of a platinum-containing automotive catalytic converter into the compulsory equipment of each car. This was the primary reason for the development of new analytical procedures for the determination of ultra-trace concentrations of these metals. Consequently, the preconcentration techniques solved the fundamental problem of these analytes in real samples and raised their concentration to a measurable level. A very detailed review of the preconcentration techniques used to determine trace amounts of PGMs pre- sents works [47]. There are described hydrophobic sorbents with surface immobilized complexing or chelating agents, complexing and chelating sorbents, fiber complexing sorbents, liquid anion exchange sorbents and extraction agents, as well as basic anion exchange sorbents.

Table 2 clearly shows the possible SPE platinum metal techniques in the coming years. Types of sorbents, sorption techniques, analytes, sorption conditions, end detection techniques and the usability for analysis of real samples are all mentioned. A very important part of the analytical determination of PGMs in environmental and biological samples is also the sample preparation step and its decomposition. In the case of water samples, the sample is only filtered through a membrane filter of predefined pore size and acidified before analysis, most often with hydrochloric acid. Acidic solution is very important in trace analysis of PGMs. It ensures the presence of PGMs in the form of soluble chlorocomplexes and prevents sorption on the walls of the containers in which the sample is stored. Solid environmental samples are usually decomposed in aqua regia by microwave decomposition, heating and evaporation to near dryness or boiling under reflux. In the case of PGMs, the fire assay method can also be used for decomposition [48]. The sample preparation procedures are given in both Table 2 and 3.

\section{Monitoring of PGMs in the environment}

Compared to other elements, PGMs are naturally found in the environment in very low concentrations, often in elemental form, and their occurrence is diffuse in nature. All PGMs always occur together. Palladium and platinum are present in the content of $0.015-0.010 \mathrm{mg} . \mathrm{kg}-1$, $\mathrm{Ru}, \mathrm{Os}, \mathrm{Rh}$ and Ir in lower concentrations of 0.005-0.0001 mg.kg-1. They naturally occur either in pure form, dispersed in alluvial placer deposits, or bound in ores in the form of arsenides and sulfides, along with other more common metals such as nickel, copper and iron. The largest deposits are found in South Africa, Russia and North America.

Although these metals are naturally rare, since the end of the 20th century their content in the environment has been steadily increasing due to human anthropogenic activity. They are used extensively in transport, industry and medicine. These are the main routes of entry into the environment for these metals and their compounds.

PGMs are used primarily for their excellent catalytic properties and are predominantly applied in industry as catalysts. Palladium is used in hydrogenation and dehydrogenation reactions, platinum as a catalyst in nitric acid production, petroleum reforming and especially both platinum and palladium in automotive catalysts. Other PGMs are used to increase the hardness of various alloys and in catalytic and hydrogenation reactions, but their greater industrial use is limited by their rarity and high cost. In recent years, the use of palladium has increased, partially replacing platinum in automotive catalysts. This is due to its availability and lower price, which has now risen because of its increased use (see Fig. 1).

Platinum-based catalysts have been used in nitric acid production for about a century. Modern nitric acid production processes consist of three steps. The first step is the oxidation of ammonia gas with air to form nitric oxide, to achieve high conversion efficiency on the platinum-rhodium catalyst. Rhodium is added to reduce platinum losses. The nitric oxide is cooled and further oxidized to nitrogen dioxide, which is then absorbed in water to form nitric acid. Platinum and rhodium losses can be as high as $300 \mathrm{mg}$ per ton of nitric acid. The end use of nitric acid is in the production of nitrogen fertilizers, an important source of plant nutrients. In this way, platinum also enters the environment and the loss of platinum from catalysts is several tons a year worldwide.

Fig. 2 shows the massive use of platinum and palladium in the production of automotive catalysts. Platinum was used for this purpose in 2018 , about $95 \mathrm{t}$, but palladium already $270 \mathrm{t}$ and rhodium only about 
Table 2

Overview of preconcentration techniques used for determination of PGMs.

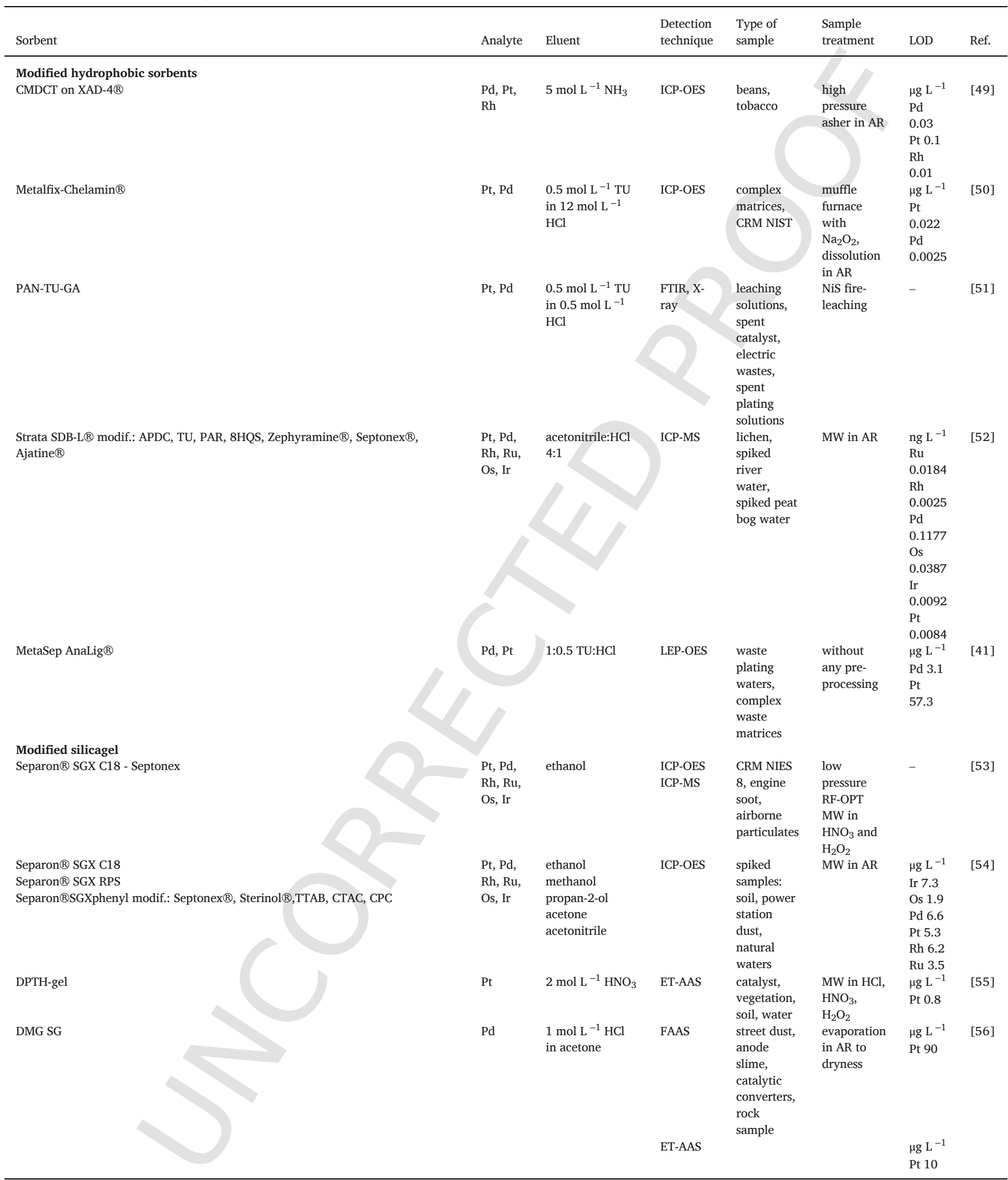


Table 2 (Continued)

\begin{tabular}{|c|c|c|c|c|c|c|c|}
\hline Sorbent & Analyte & Eluent & $\begin{array}{l}\text { Detection } \\
\text { technique }\end{array}$ & $\begin{array}{l}\text { Type of } \\
\text { sample }\end{array}$ & $\begin{array}{l}\text { Sample } \\
\text { treatment }\end{array}$ & LOD & Ref. \\
\hline DPTH-gel & $\mathrm{Pd}$ & $4 \mathrm{~mol} \mathrm{~L}^{-1} \mathrm{HCl}$ & ET-AAS & CRM NIST & MW in AR & $\begin{array}{l}\mu \mathrm{g} \mathrm{L}^{-1} \\
\operatorname{Pd} 0.4\end{array}$ & [57] \\
\hline & & & & $\begin{array}{l}\text { lentil, } \\
\text { bovine } \\
\text { liver, } \\
\text { vegetation }\end{array}$ & $\begin{array}{l}\mathrm{MW} \text { in } \\
\mathrm{HNO}_{3} \\
\mathrm{H}_{2} \mathrm{O}_{2}\end{array}$ & & \\
\hline PAMAM SG & Pd & $0.2 \% \mathrm{TU}$ & F-AAS & $\begin{array}{l}\text { nickel } \\
\text { alloy, } \\
\text { anode } \\
\text { slime }\end{array}$ & $\begin{array}{l}\mathrm{Na}_{2} \mathrm{CO}_{3} \\
\mathrm{Na}_{2} \mathrm{O}_{2} \\
\text { dissolution } \\
\text { in AR }\end{array}$ & $\begin{array}{l}\mu g L^{-1} \\
\operatorname{Pd} 3.9\end{array}$ & [58] \\
\hline DKTS APSG & Pd & $\mathrm{TU}$ in $\mathrm{HCl}$ & F-AAS & $\begin{array}{l}\text { catalytic } \\
\text { converter, } \\
\text { spiked tap }\end{array}$ & $\begin{array}{l}\text { evaporation } \\
\text { in AR to } \\
\text { dryness }\end{array}$ & $\begin{array}{l}\mu g \mathrm{~L}^{-1} \\
\operatorname{Pd} 5\end{array}$ & [59] \\
\hline $\begin{array}{l}\text { Bond-Elut C18 }{ }^{\circledR} / \text { Septonex }{ }^{\circledR} \\
\text { Strata C18-E®/Septonex }{ }^{\circledR}\end{array}$ & Pt & acetonitrile & ET-AAS & $\begin{array}{l}\text { airborne } \\
\text { urban dust }\end{array}$ & MW in AR & $\begin{array}{l}\mu g \mathrm{~L}^{-1} \\
\mathrm{Pt}\end{array}$ & [27] \\
\hline SAX sorbent & Pt, Pd & $\begin{array}{l}2 \mathrm{~mol} \mathrm{~L}^{-1} \\
\text { in } 1.2 \mathrm{~mol} \mathrm{~L}^{-1} \\
\mathrm{HCl}\end{array}$ & ICP-MS & $\begin{array}{l}\text { CRM BCR } \\
\text { 723, road } \\
\text { dust }\end{array}$ & $\begin{array}{l}\mathrm{MW} \text { in } \\
\mathrm{HNO}_{3} \\
\mathrm{H}_{2} \mathrm{O}_{2}, \mathrm{HCl} \\
\mathrm{HF}\end{array}$ & $\begin{array}{l}1.137 \\
\text { ng/g } \\
\text { Pt } 2 \\
\text { Pd } 1\end{array}$ & {$[60]$} \\
\hline 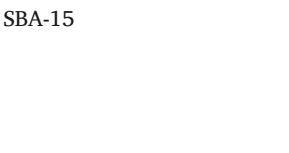 & Pt & TU & ET-AAS & $\begin{array}{l}\text { platinum } \\
\text { ore CRM } \\
\text { SARM 7, } \\
\text { geological } \\
\text { samples }\end{array}$ & $\begin{array}{l}\mathrm{MW} \text { in } \\
\mathrm{HNO}_{3}\end{array}$ & - & [61] \\
\hline Bond-Elut C18 $\AA /$ Septonex $\AA$ & Pt, Pd & ace & ET-AAS & $\begin{array}{l}\text { lichen, } \\
\text { moss, } \\
\text { needle }\end{array}$ & $\begin{array}{l}\text { boiling } \\
\text { under } \\
\text { reflux in } \\
\text { AR }\end{array}$ & $\begin{array}{l}\mu \mathrm{g} \mathrm{L}^{-1} \\
\mathrm{Pt} \\
2.627 \\
\mathrm{Pd} \\
2.282\end{array}$ & [32] \\
\hline & & & & $\begin{array}{l}\text { soil, tunnel } \\
\text { dust }\end{array}$ & $\mathrm{MW}$ in $\mathrm{AR}$ & $\begin{array}{l}\mu g \mathrm{~L}^{-1} \\
\mathrm{Pt} \\
1.14\end{array}$ & [29] \\
\hline SBA-15 & Pd & $0.6 \mathrm{~mol} \mathrm{l}^{-1} \mathrm{TU}$ & ET-AAS & $\begin{array}{l}\text { soil, road } \\
\text { dust }\end{array}$ & $\mathrm{MW}$ in $\mathrm{AR}$ & $\begin{array}{l}\mu \mathrm{g} \mathrm{L}^{-1} \\
\mathrm{Pd} \\
0.048\end{array}$ & [62] \\
\hline $\begin{array}{l}\text { Bond-Elut C18®/DMG } \\
\text { QuadraSil }^{\mathrm{TM}} \mathrm{TA}\end{array}$ & $\mathrm{Pd}$ & $\begin{array}{l}1 \mathrm{~mol} \mathrm{~L}^{-1} \\
\text { in ethanol } \\
0.05 \mathrm{~mol} \mathrm{~L}^{-1} \mathrm{TU}\end{array}$ & ET-AAS & lichen & $\begin{array}{l}\text { boiling } \\
\text { under } \\
\text { reflux in } \\
\text { AR }\end{array}$ & $\begin{array}{l}\mu \mathrm{g} \mathrm{L}^{-1} \\
\mathrm{Pd} \\
1.110\end{array}$ & [63] \\
\hline $\begin{array}{l}\text { Anion exchangers } \\
\text { Amberlite }{ }^{\circledR} \text { IRA-68 } \\
\text { Amberlite }{ }^{\circledR} \text { IRA-93 } \\
\text { Amberlite }{ }^{\circledR} \text { IRA-400 }\end{array}$ & $\begin{array}{l}\text { Pt, Pd, } \\
\text { Rh }\end{array}$ & $4 \mathrm{~mol} \mathrm{l}^{-1} \mathrm{HCl}$ & ICP-OES & $\begin{array}{l}\text { catalytic } \\
\text { converters }\end{array}$ & $\begin{array}{l}\text { leaching in } \\
\mathrm{HCl} \text {, } \\
\mathrm{NaClO}_{3}\end{array}$ & - & [64] \\
\hline Dowex® 1-X8 & $\begin{array}{l}\text { Pt, Pd, } \\
\text { Rh, Ir, } \\
\text { Ru }\end{array}$ & $\begin{array}{l}0.3 \mathrm{~mol} \mathrm{~L}^{-1} \mathrm{TU} \\
\text { in } 0.1 \mathrm{~mol} \mathrm{~L}^{-1} \\
\mathrm{HCl}\end{array}$ & ICP-MS & $\begin{array}{l}\text { synthetic } \\
\text { PGMs } \\
\text { solution }\end{array}$ & - & $\begin{array}{l}\mu \mathrm{g} \mathrm{L}^{-1} \\
\text { Ru } 14 \\
\text { Rh } 11 \\
\text { Pd } 13 \\
\text { Ir } 9 \\
\text { Pt } 29 \\
\mu g \mathrm{~L}^{-1} \\
\text { Ru } \\
0.22 \\
\text { Rh } \\
0.03 \\
\text { Pd } \\
0.17 \\
\text { Ir } 0.07 \\
\text { Pt } \\
0.11\end{array}$ & [65] \\
\hline Dowex ${ }^{\circledR}$ 1-X10 & Pt & $\begin{array}{l}0.1 \mathrm{~mol} \mathrm{~L}^{-1} \mathrm{TU} \\
\mathrm{v} 0.1 \mathrm{~mol} \mathrm{~L}^{-1} \\
\mathrm{HCl}\end{array}$ & ICP-OES & road dust & $\begin{array}{l}\text { heating in } \\
\mathrm{AR}\end{array}$ & $\begin{array}{l}\mu \mathrm{g} \mathrm{L}^{-1} \\
\text { Pt } 15 \\
\text { Pd } 19\end{array}$ & [66] \\
\hline PSTH Dowex® 1-X8 & Pt & $2 \mathrm{~mol} \mathrm{~L}^{-1} \mathrm{HNO}_{3}$ & ET-AAS & $\begin{array}{l}\text { catalyst, } \\
\text { CRM NIST } \\
2557, \text { soil }\end{array}$ & MW in AR & $\begin{array}{l}\mu g \mathrm{~L}^{-1} \\
\text { Pt } 1\end{array}$ & [67] \\
\hline
\end{tabular}


Table 2 (Continued)

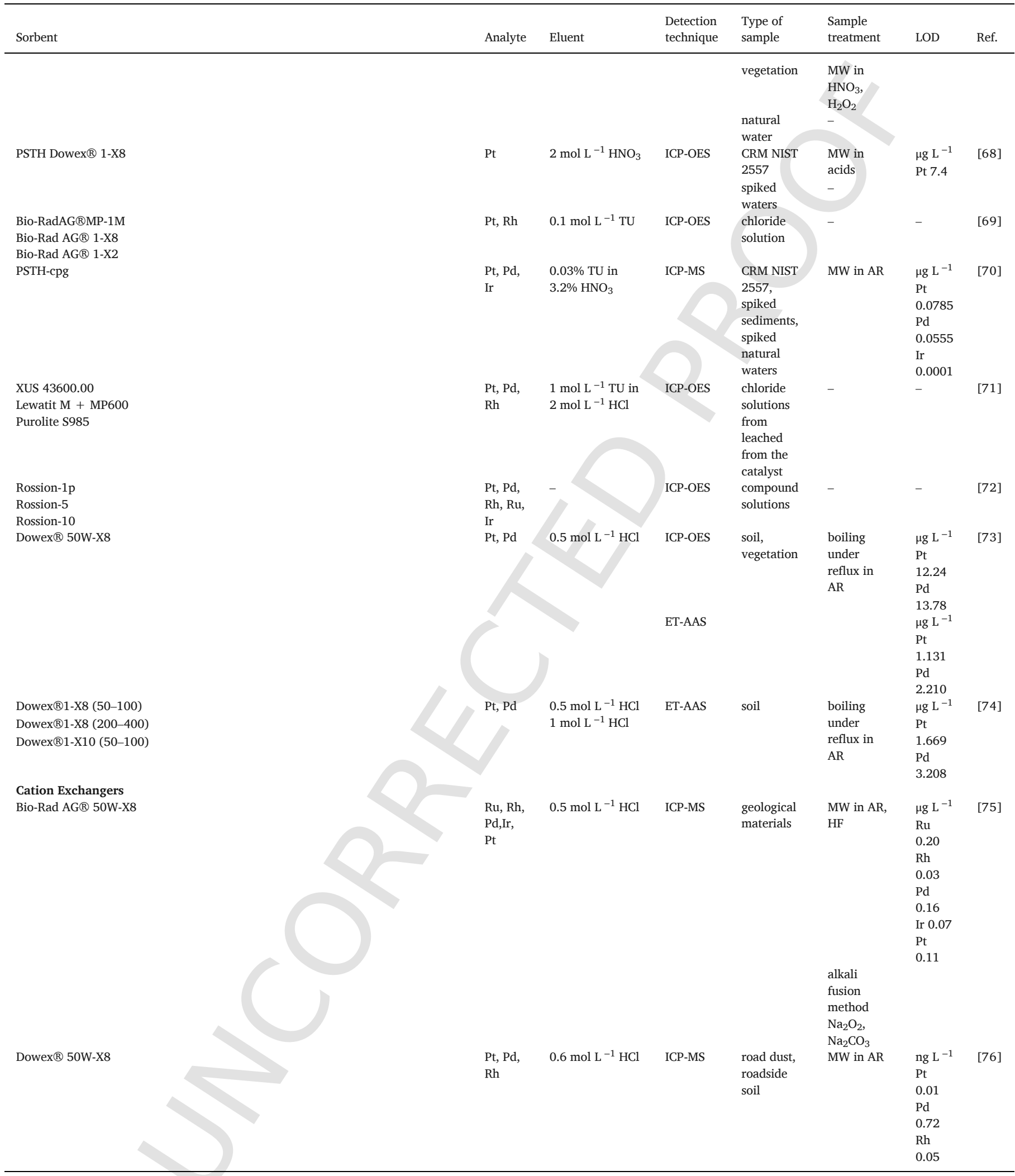




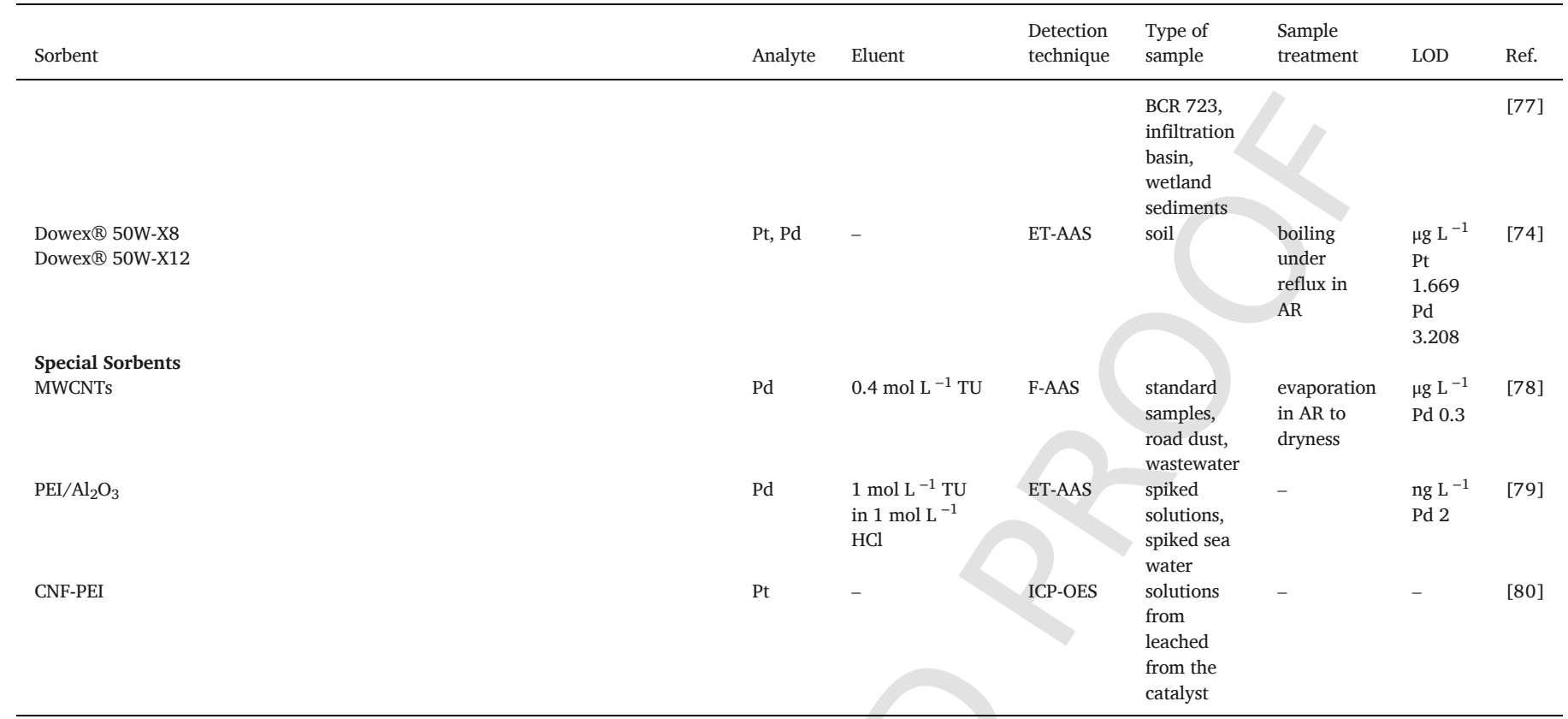

27 t. Over time, more and more precious metals are recycled. In 2018, almost $65 \mathrm{t}$ of platinum, $100 \mathrm{t}$ of palladium and about $11 \mathrm{t}$ of rhodium were recycled from the used autocatalysts. Recycled automotive catalysts can contain up to 2000 g.t- 1 platinum, which is a significantly higher quantity than is found in the ores from which it is extracted. These high levels of platinum in waste make it, economically, very interesting when compared to the economic side of ore mining.

Road transport is the largest source of platinum metal pollution. There are studies that estimate up to a $40 \%$ release of PGMs from catalysts into the environment during the first 100,000 km travelled by a car [81]. PGMs emissions have been proven, both by testing the emission gases in laboratories and by determining their presence in environmental compartments. This release from the catalyst is due to the chemical and physical processes taking place on the catalytic surface. They are released due to mechanical abrasion, a high operating temperature and ongoing oxidation-reduction reactions. The release is further influenced by a number of factors, such as speed and driving style, start-stop driving, operating temperature, fuel type and quality, the age of the catalytic converter and, in particular, the engine type. The diesel engine produces significantly higher emissions than the gasoline engine with a three-way catalytic converter. Depending on these conditions, emissions can range from ng to $\mu \mathrm{g}$ PGMs per $1 \mathrm{~km}$ of driving, representing their contents in contaminated air around busy roads at pg.m-3 [27]. However, the exact amount of platinum released cannot be predicted, given the abundance of factors and research over 30 years.

The PGMs emitted are most often in the form of metal nanoparticles, which can be adsorbed onto the catalyst support (Al2O3) or exhaust gas (soot) particles. These particles become part of the polluted atmosphere and, depending on their size, are deposited at different distances from the source of pollution, depending on the density of car traffic, meteorological conditions and terrain morphologies. They adhere to dust, surface soil and vegetation around roads and, under certain conditions, may also be subject to long-distance transport. This is evidenced by the finding of increased concentrations of PGMs in snow and ice in European mountain areas and in Greenland, with a significant increase in the 1990s [81]. The advantage of analyzing different layers of ice is the chronological information that can indicate the time of contamination.

Another important source of PGMs emissions is medicine. Platinum-based drugs, especially cisplatin, cis-diaminodichloro Pt (II), and carboplatin, cis- (diamine-1,1-cyclobutane-1,1-dicarboxylato) Pt (II), have been widely used as effective cytostatics since the early 1970s. The principle of the anti-tumor effect of cisplatin is to inhibit DNA synthesis by forming cross-links in and between DNA strands. In addition to inhibiting DNA synthesis, cisplatin has immunosuppressive, radio sensitizing and antibacterial properties. It is used to treat a wide range of cancers: bronchogenic carcinoma, testicular carcinoma, ovarian carcinoma, cervical carcinoma, endometrium, prostate, bladder, melanoma, sarcomas, ENT tumors, brain epithelial carcinoma and malignant lymphomas [82]. In contrast to its therapeutic effects, cisplatin has a number of negative effects on the treated patient. When used, cisplatin has nephrotoxic, neuropathic, ototoxic effects, allergic manifestations and is suspected of having a possible carcinogenicity and many other undesirable side effects. The excretion of cisplatin, as well as other platinum metallopharmaceuticals, takes place exclusively in urine and bile. In the first five days, $27-43 \%$ of cisplatin is excreted. In this way, platinum gets into the waste water, not only of treatment facilities, but also of households after the patients leave home. Its concentrations are in ng.l-1 [22].

The main problem with the occurrence of platinum drugs in wastewater is the presence of platinum in a soluble, bioavailable and highly toxic form, as opposed to the more inert metallic forms of platinum emitted by automobile catalysts. However, it may be partially present in the form of surface oxidized particles. These are more easily subjected to complex reactions and produce bioavailable forms of platinum, most often in the form of chlorocomplexes or complexes with organic ligands. The most common ligands complexing platinum are phosphates (from phosphate fertilizers), chlorides (from road surface maintenance in the winter months), citrates (produced by plant roots) and fulvic acids (produced by natural decomposition of organic matter) [83]. So far, there is very little relevant information on the bioavailability of PGMs, their ecotoxicity and environmental fate. 
Table 3

Overview of PGMs concentration in selected environmental and biological objects.

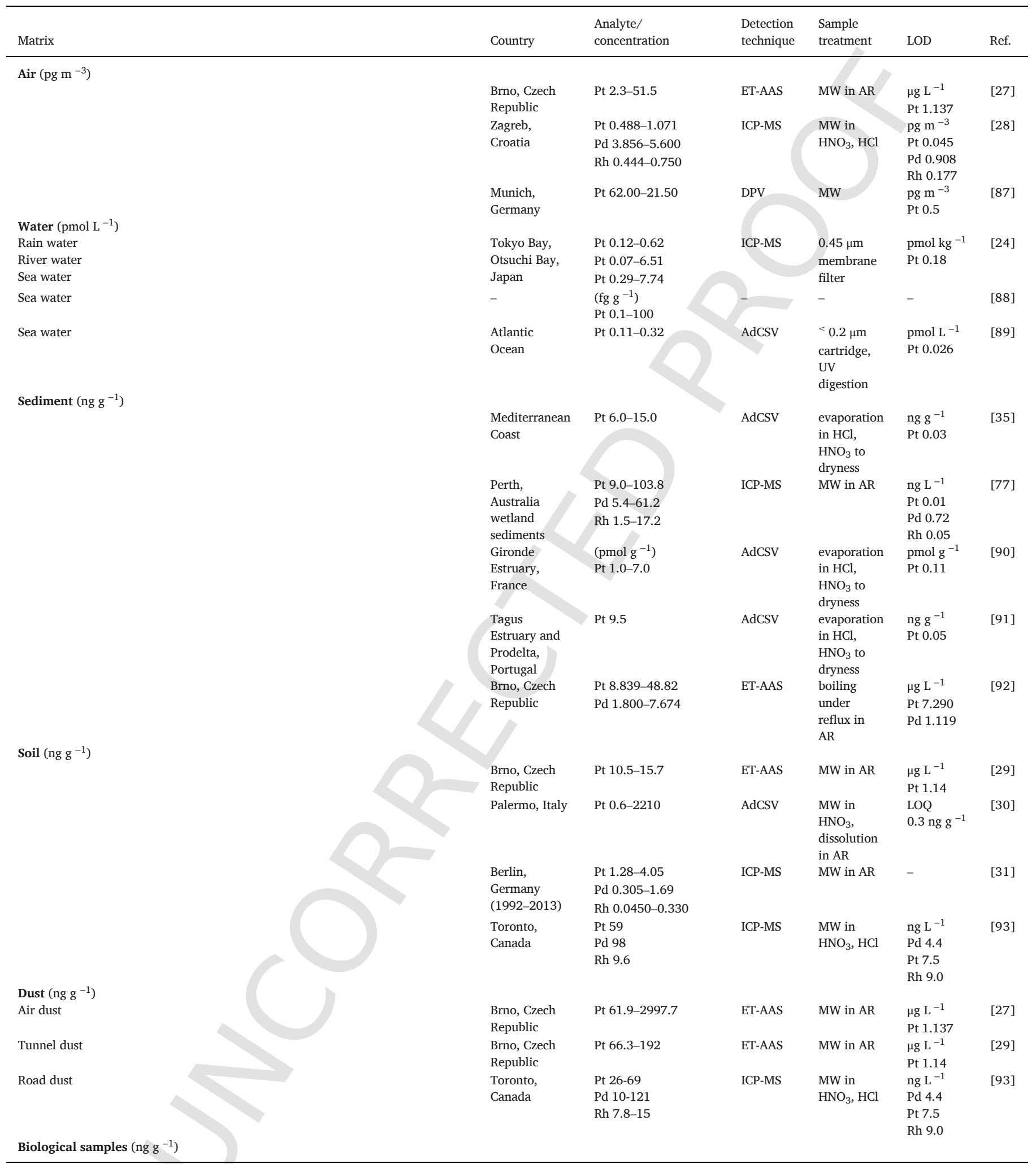


Table 3 (Continued)

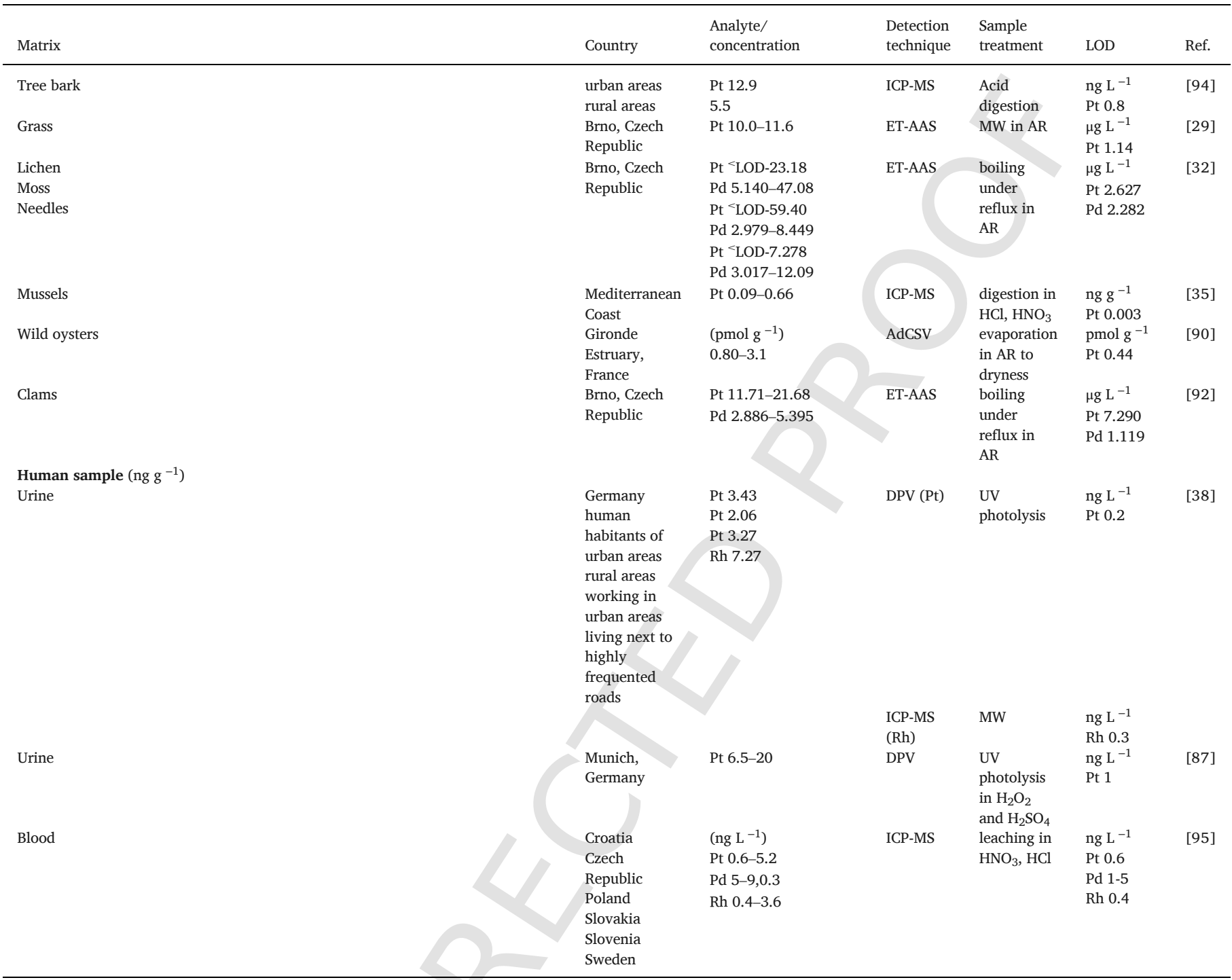

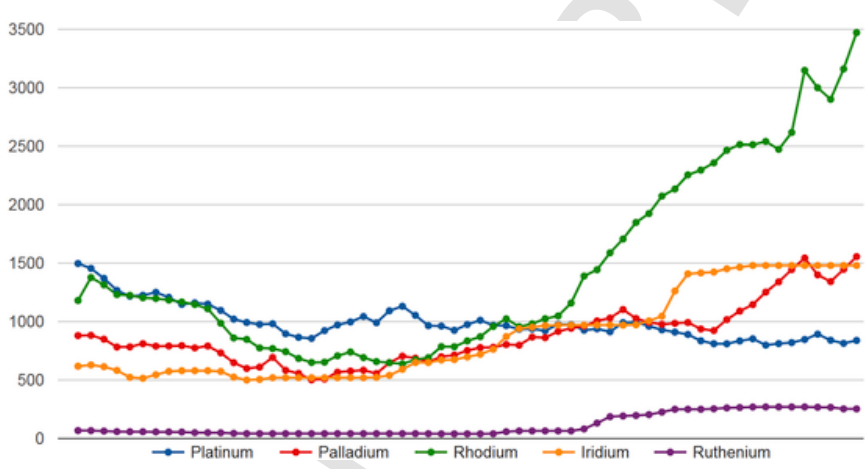

Fig. 1. Average monthly prices (x-axis months, $y$-axis $\$ / \mathrm{oz}, 1 \mathrm{oz}-31.1035 \mathrm{~g}$ ) of PGMs in 2014-2019 Ref. [3].

An important parameter is the mobility of platinum compounds in individual environmental compartments. This is clearly dependent on the form of PGMs, the $\mathrm{pH}$ of the soils, the redox potential and the presence of the above complexing agents. It is estimated that about $10 \%$ of the platinum emitted from autocatalysts is water soluble under environ- mental conditions. For palladium and rhodium, a solubility of even $50 \%$ is expected [11], as well as higher bioavailability. It was experimentally determined in the order of $\mathrm{Pd}>\mathrm{Pt} \geq \mathrm{Rh}$, when the transformation coefficient (ratio of metal concentrations in the plant and in the soil from which the plant grows) was tested. Therefore, palladium is the most soluble, mobile and bioavailable of all PGMs. The highest concentrations were found in plant roots where binding to sulfur-containing substances, in animal bodily fluids and in bird feathers [84].

Blood proteins play a decisive role in the transport of PGMs in animal bodies. Up to $80 \%$ of platinum in the blood is found in erythrocytes. The stability of protein binding depends on the type of compound. Elevated concentrations were detected in the kidneys and liver, where they bind to metallothionenins (proteins with cysteine). These proteins have a high affinity for all heavy metals (Cd, $\mathrm{Cu}, \mathrm{Hg}$, etc.) and their formation is indicated by the presence of these risk elements. The presence of Pt (II) induces the formation of metallothioneines and binds them up to 100 times faster than other heavy metals, so they can be displaced. Relevant information on the behavior of other PGMs and their compounds is not yet known. Similarly, there is no known information on the biotransformation reactions of PGMs by the formation of 
A.

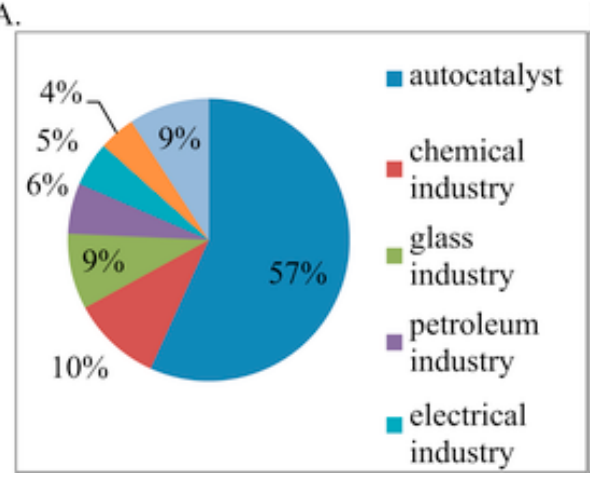

B.

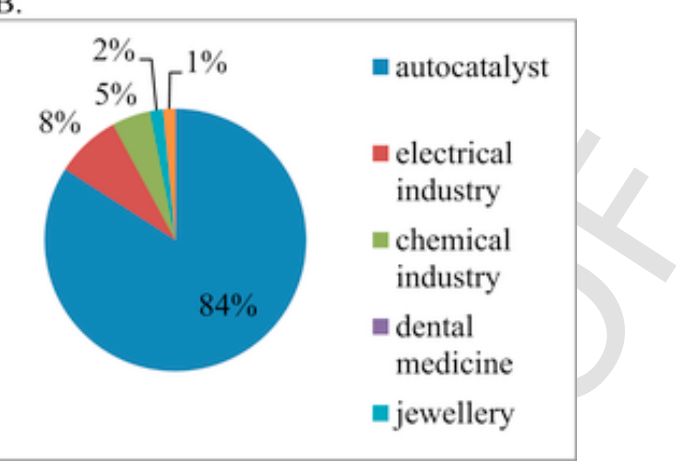

Fig. 2. Use of A. platinum and B. palladium in 2018, according to Ref. [3].

methyl compounds. Only laboratory studies have been conducted and there is no direct evidence of methylation of PGMs in environmental compartments.

The environmental toxicity of PGMs is clearly dependent on their size (in the case of emitted particles), their form and the compounds in which they occur. In elemental metal form they are inert, but in the form of nanoparticles their toxicity increases due to dissolution, oxidation and complexing reactions, under both biotic and abiotic conditions. Platinum nanoparticles may enter into different parts of the plant [85] and can also affect local physico-chemical processes in the soil [86]. From WHO materials $[14,15]$, providing data only for platinum and palladium, there is a risk of particulate inhalation and allergic properties. Pd (II) is even the most common sensitizer of all metals. The greatest risk lies, primarily, for people living in polluted areas with chronic exposure to them. At present, they have been found in large urban agglomerations contents of PGMs in all parts of the environment. Their quantity is growing steadily and strongly depends on the density of automobile traffic. Therefore, the inhabitants of these areas make up the most vulnerable population $[13,29,32,81]$, and [84].

The analysis of the individual components of the environment can be done in several ways. When analyzing the polluted atmosphere, samples of solid particles of airborne dust are collected by trapping on glass fiber filters using an automatic sampler, by sucking the polluted air. These filters are then analyzed and the analyte concentration in the atmosphere can be determined from the volume of sieved air during sampling, most often in units of pg.m-3 for PGMs. Using 24-h sampling, the analyte can be concentrated on the filter to a measurable value. When interpreting the results and drawing conclusions, it is necessary to take into account the sampling conditions (season, sampling time - working days, weekends, traffic intensity, meteorological conditions, etc.).

The most easily analyzable matrix is water and aqueous solutions. A disadvantage in the analysis of environmental water samples is the very low content of PGMs, which are in units of ng.l-1. In this case, it is necessary to use preconcentration techniques to enrich the analyte to a measurable concentration value. It is thus possible to increase the analyte content in the analyzed sample by one order, with respect to the used end detection instrumental analytical technique.

Sediment analysis is very closely related to the analysis of natural water. For a complete overview of the behavior of PGMs in water, an interesting analyte is sediment taken from the same location as the water sample. However, complications and losses of the analyte may occur when sediment is sampled. When assessing the platinum content of sediments, one should take note of the possible inhomogeneity of sediment samples and the influence of local conditions (the presence of other pollutants, flow behavior at the sampling site, climatic and meteorological conditions, etc.).
Very often, the analyzed material is the soil around busy roads. When collecting the soil, a number of factors should be taken into account: distance of the sampling site from the potential source of contamination (from the road), depth of sampling, traffic intensity at the site, local conditions (the presence of vegetation, barriers, etc.), climatic conditions and meteorological conditions.

Road dust is also an important matrix for assessing the state of environmental pollution from automobile traffic. Its sampling is more demanding and safety rules for sampling must be observed, especially when it comes to tunnel dust sampling. This matrix has the highest content of PGMs, as confirmed by the data in Table 3 .

For a comprehensive overview of the distribution of PGMs in environmental components, it is also necessary to determine their content in biological matrices, so-called bioindicators. For this purpose, there is an effective tool: biomonitoring. By means of biomonitoring, it is possible to find relationships between the pollution of individual components of the environment (air, aquatic and terrestrial ecosystems) and organisms living within it. Possible adverse effects on human health can also be predicted from biomonitoring data.

A bioindicator is an organism that indicates the environmental pollution by selected pollutants. Plant bioindicators are most commonly used and are divided into sensitive, accumulative and test bioindicators. In the case of the biomonitoring of PGMs, accumulation bioindicators, with the ability to accumulate pollutants from environmental components, are used. These substances accumulate in the body without causing visible damage and their uptake depends on their concentration in the environment. These bioindicators can be analyzed immediately after collection - passive bioindications, or using active (exposure) bioindications. Selected plant species are deliberately exposed to the polluted environment and react by accumulating pollutants (accumulative indicator). Bioindicators that are easily and available year-round include mosses, lichens and pine needles. These bioindicators have the advantage of being evergreen and can be sampled throughout the year. In addition, mosses and lichens have a large surface area that is not covered with a cuticle. This allows for the uptake of pollutants from the atmosphere almost exclusively by the particle deposition process. Furthermore, grass vegetation samples are often analyzed, together with soil analysis, for platinum metal content. Sampling conditions for biological samples should also be taken into account. In particular, season, climatic and meteorological conditions, type of sample, and distance from the source of contamination.

A current overview of the occurrence of PGMs in the environment, indicating the location and analytical detection techniques, is shown in Table 3. 


\section{Conclusion}

It is clear from the above that PGMs affect us all. The issues stemming from their use are global, whether in terms of resources, their use in industry, applications, automotive use, waste and wastewater management and environmental contamination, not only from a local, but also from a global perspective. Emission limits from automotive sources are getting steadily tighter throughout the world and the necessary use of PGMs to reduce emissions contributes to an upward trend in global platinum, palladium and rhodium levels.

The most commonly used method for the determination of PGMs is the ICP-MS technique, providing highly sensitive simultaneous multi-elementary ability. Trace values of PGMs can also be determined by atomic absorption and emission techniques, ET-AAS and ICP-OES. Voltammetric methods also show high sensitivity. Trace concentrations of PGMs in environmental and biological samples often require appropriate methods and procedures for separation and preconcentration prior to their analytical determination. The preconcentration of PGMs therefore includes especially innovative or newly developed sorption techniques mentioned in this work. Modified hydrophobic sorbents, which include in particular modified silica gel and anion exchange sorbents, are most commonly used. Sorbents of the nanotubes and nanofibers type, often modified to increase the sorption selectivity of PGMs, are also newly used. When analyzing using the preconcentration technique, it is always necessary to take into account all relevant factors, such as the sample type, the method of sample decomposition, the matrix effect, using eluent and the end detection technique with required detection limit. Preconcentration techniques can be used to increase the concentration of PGMs to a value measurable by more common analytical techniques such as ET-AAS and ICP-OES.

There are many other challenges in determining ultra-trace concentrations of PGMs, given their presence in the environment in the form of nanoparticles, and the fact that the oxidation state, speciation, and the form of occurrence significantly affect the reactivity, bioavailability and toxic properties of PGMs.

\section{Acknowledgements}

This work was funded by the Ministry of Education, Youth and Sports (FCH-S-19-5971).

\section{References}

[1] F. Reith, S. Campbell, A. Ball, A. Pring, G. Southam, Platinum in Earth surface environments, Earth Sci. Rev. 131 (2014) 1-21, doi:10.1016/ j.earscirev.2014.01.003.

[2] C. Rao, G. Reddi, Platinum group metals (PGM); occurrence, use and recent trends in their determination, Trac. Trends Anal. Chem. 19 (2000) 565-586, doi:10.1016/S0165-9936(00)00031-5.

[3] Matthey Johnsonhttp://www.platinum.matthey.com201918 October 2019

[4] G. Mudd, S. Jowitt, T. Werner, Global platinum group element resources, reserves and mining - a critical assessment, Sci. Total Environ. 622-623 (2018) 614-625, doi:10.1016/j.scitotenv.2017.11.350.

[5] Y. Ding, S. Zhang, B. Liu, H. Zheng, C. Chang, C. Ekberg, Recovery of precious metals from electronic waste and spent catalysts: a review: a review, Resour. Conserv. Recycl. 141 (2019) 284-298, doi:10.1016/j.resconrec.2018.10.041.
[6] L. Bencs, K. Ravindra, R. Van Grieken, Platinum: environmental pollution and health effects, Elsevier, Burlington, 2011, pp. 580-595, doi:10.1016/ B978-0-444-52272-6.00602-4.

[7] S. Rauch, H. Hemond, C. Barbante, M. Owari, G. Morrison, B. Peucker-Ehrenbrink, U. Wass, Importance of automobile exhaust catalyst emissions for the deposition of Platinum, Palladium and Rhodium in the Northern hemisphere, Environ. Sci. Technol. 39 (2005) 8156-8162.

[8] J. Kielhorn, C. Melber, D. Keller, I. Mangelsdorf, Palladium - a review of exposure and effects to human health, Int. J. Hyg Environ. Health 205 (2002) 417-432, doi:10.1078/1438-4639-00180.

[9] K. Ek, G. Morrison, S. Rauch, Environmental routes for platinum group elements to biological materials-a review, Sci. Total Environ. 334-335 (2004) 21-38, doi:10.1016/j.scitotenv.2004.04.027.

[10] K. Ravindra, L. Bencs, R. Van Grieken, Platinum group elements in the environment and their health risk, Sci. Total Environ. 318 (2004) 1-43, doi:10.1016/ S0048-9697(03)00372-3.

[11] C. Wiseman, F. Zereini, Airborne particulate matter, platinum group elements and human health: a review of recent evidence: a review of recent evidence, Sci. Total Environ. 407 (2009) 2493-2500, doi:10.1016/ j.scitotenv.2008.12.057.

[12] F. Annesofie, M. Torkil, J. D, T. P, Metal allergen of the 21st century-a review on exposure, epidemiology and clinical manifestations of palladium allergy, Contact Dermatitis 64 (2011) 185-195, doi:10.1111/ j.1600-0536.2011.01878.x.

[13] J. Pawlak, E. Łodyga-Chruścińska, J. Chrustowicz, Fate of platinum metals in the environment, J. Trace Elem. Med. Biol. 28 (2014) 247-254, doi:10.1016/ j.jtemb.2014.03.005.

[14] G. Rosner, D. Coenen-Stass, H. König, Environmental health criteria, 125 (1991). http://www.inchem.org/documents/ehc/ehc/ehc125.htm. [accessed 8 March 2018].

[15] C. Melber, D. Keller, I. Mangelsdorf, Environmental health criteria, 226 (2002). http://www.inchem.org/documents/ehc/ehc/ehc226.htm. [accessed 25 February 2019].

[16] C. Ojeda, F. Rojas, J. Pavón, Determination of platinum by graphite furnace atomic absorption spectrometry in foods and beverages using an automated on-line separation-preconcentration system, Food Control 17 (2006) 365-369, doi:10.1016/j.foodcont.2005.01.002.

[17] W. Mortada, M. Hassanien, A. El-Asmy, Speciation of platinum in blood plasma and urine by micelle-mediated extraction and graphite furnace atomic absorption spectrometry, J. Trace Elem. Med. Biol. 27 (2013) 267-272, doi:10.1016/ j.jtemb.2013.04.004.

[18] N. Vyas, A. Turner, G. Sewell, Platinum-based anticancer drugs in waste waters of a major UK hospital and predicted concentrations in recipient surface waters, Sci. Total Environ. 493 (2014) 324-329, doi:10.1016/j.scitotenv.2014.05.127.

[19] A. Turner, L. Mascorda, Particle-water interactions of platinum-based anticancer drugs in river water and estuarine water, Chemosphere 119 (2015) 415-422, doi:10.1016/j.chemosphere.2014.06.074.

[20] A. Garoufis, S. Hadjikakou, N. Hadjiliadis, Palladium coordination compounds as anti-viral, anti-fungal, anti-microbial and anti-tumor agents, Coord. Chem. Rev. 253 (2009) 1384-1397, doi:10.1016/j.ccr.2008.09.011.

[21] B. Mavroidi, M. Sagnou, K. Stamatakis, M. Paravatou-Petsotas, M. Pelecanou, C. Methenitis, Palladium(II) and platinum(II) complexes of derivatives of 2-(4'-aminophenyl)benzothiazole as potential anticancer agents, Inorg. Chim. Acta 444 (2016) 63-75, doi:10.1016/j.ica.2016.01.012.

[22] J. Vidmar, A. Martinčič, R. Milačič, J. Ščančar, Speciation of cisplatin in environmental water samples by hydrophilic interaction liquid chromatography coupled to inductively coupled plasma mass spectrometry, Talanta 138 (2015) 1-7, doi:10.1016/j.talanta.2015.02.008.

[23] K. Lenz, G. Koellensperger, S. Hann, N. Weissenbacher, S. Mahnik, M. Fuerhacker, Fate of cancerostatic platinum compounds in biological wastewater treatment of hospital effluents, Chemosphere 69 (2007) 1765-1774, doi:10.1016/j.chemosphere.2007.05.062.

[24] A. Mashio, H. Obata, H. Tazoe, M. Tsutsumi, A. Ferrer i Santos, T. Gamo, Dissolved platinum in rainwater, river water and seawater around Tokyo Bay and Otsuchi Bay in Japan, Estuarine, Estuar. Coast Shelf Sci. 180 (2016) 160-167, doi:10.1016/j.ecss.2016.07.002.

[25] M. Chen, S. Chen, M. Du, S. Tang, M. Chen, W. Wang, H. Yang, Q. Chen, J. Chen, Toxic effect of palladium on embryonic development of zebrafish, Aquat Toxicol. 159 (2015) 208-216, doi:10.1016/j.aquatox.2014.12.015. 
[26] S. Zimmermann, C. Wolff, B. Sures, Toxicity of platinum, palladium and rhodium to Daphnia magna in single and binary metal exposure experiments, Environ. Pollut. 224 (2017) 368-376, doi:10.1016/j.envpol.2017.02.016.

[27] H. Kosarova, R. Komendova, R. Skeril, Development of an analytical method for the determination of platinum in urban dust in the agglomeration of Brno, Czech Republic, Fresenius Environ. Bull. 24 (2015) 2070-2075 Go to ISI:// WOS:000371185200010.

[28] J. Rinkovec, G. Pehnec, R. Godec, S. Davila, I. Bešlić, Spatial and temporal distribution of platinum, palladium and rhodium in Zagreb air, Sci. Total Environ. 636 (2018) 456-463, doi:10.1016/j.scitotenv.2018.04.295.

[29] R. Komendova, S. Jezek, The distribution of platinum in the environment in large cities: a model study from Brno, Czech Republic, Int. J. Environ. Sci. Technol. 16 (2019) 3109-3116, doi:10.1007/s13762-018-1954-x.

[30] S. Orecchio, D. Amorello, Platinum levels in urban soils from Palermo (Italy); Analytical method using voltammetry, Microchem. J. 99 (2011) 283-288, doi:10.1016/j.microc.2011.05.016.

[31] M. Birke, U. Rauch, J. Stummeyer, H. Lorenz, B. Keilert, A review of platinum group element (PGE) geochemistry and a study of the changes of PGE contents in the topsoil of Berlin, Germany, between 1992 and 2013, J. Geochem. Explor. 187 (2018) 72-96, doi:10.1016/j.gexplo.2017.09.005.

[32] R. Komendova, The use of bioindicators for assessing atmospheric pollution with platinum metals, Fresenius Environ. Bull. 5A (2018) 3444-3451.

[33] H. Gawrońska, A. Przybysz, E. Szalacha, K. Pawlak, K. Brama, A. Miszczak, M. Stankiewicz-Kosyl, S. Gawroński, Platinum uptake, distribution and toxicity in Arabidopsis thaliana L. plants, Ecotoxicol. Environ. Saf. 147 (2018) 982-989, doi:10.1016/j.ecoenv.2017.09.065.

[34] K. Kümmerer, E. Helmers, P. Hubner, G. Mascart, M. Milandri, F. Reinthaler, M. Zwakenberg, European hospitals as a source for platinum in the environment in comparison with other sources, Sci. Total Environ. 225 (1999) 155-165, doi:10.1016/S0048-9697(98)00341-6.

[35] M. Abdou, J. Schäfer, R. Hu, T. Gil-Díaz, C. Garnier, C. Brach-Papa, J. Chiffoleau, S. Charmasson, F. Giner, L. Dutruch, G. Blanc, Platinum in sediments and mussels from the northwestern Mediterranean coast: temporal and spatial aspects: temporal and spatial aspects, Chemosphere 215 (2019) 783-792, doi:10.1016/j.chemosphere.2018.10.011.

[36] K. Ek, S. Rauch, G. Morrison, P. Lindberg, Platinum group elements in raptor eggs, faeces, blood, liver and kidney, Sci. Total Environ. 334-335 (2004) 149-159, doi:10.1016/j.scitotenv.2004.04.067.

[37] Y. Wang, X. Li, Health risk of platinum group elements from automobile catalysts, Procedia Eng. 45 (2012) 1004-1009, doi:10.1016/j.proeng.2012.08.273.

[38] S. Munker, S. Kilo, C. Röß, P. Jeitner, R. Schierl, T. Göen, H. Drexler, Exposure of the German general population to platinum and rhodium - Urinary levels and determining factors, Int. J. Hyg Environ. Health 219 (2016) 801-810, doi:10.1016/j.ijheh.2016.07.019.

[39] R. Thomas, Practical Guide to ICP-MS, 1 ed., CRC Press, New York, 2008. http: //algol.fis.uc.pt/jap/ICP-MS-Primer-Thomas.pdf. [accessed 17 October 2019].

[40] AAS, GFAAS, ICP or ICP-MS? Which technique should I use?, 1 ed., Thermo Elemental, United Kingdom, 2001. http://oliver.chemistry.ucsc.edu/122/ Lab5\%20Handout.pdf. [accessed 17 October 2019].

[41] S. Barua, I. Rahman, M. Miyaguchi, A. Mashio, T. Maki, H. Hasegawa, On-site analysis of gold, palladium, or platinum in acidic aqueous matrix using liquid electrode plasma-optical emission spectrometry combined with ion-selective preconcentration, Sens. Actuators B Chem. 272 (2018) 91-99, doi:10.1016/ j.snb.2018.05.132.

[42] V. Camel, Solid phase extraction of trace elements, Spectrochim. Acta B At. Spectrosc. 58 (2003) 1177-1233, doi:10.1016/S0584-8547(03)00072-7.

[43] V. Camel, Solid-phase extraction, in: Sample Preparation for Trace Element Analysis, Elsevier (2003) 393-457, doi:10.1016/S0166-526X(03)41014-3.

[44] R. Marcinkowska, K. Konieczna, Ł. Marcinkowski, J. Namieśnik, A. Kloskowski, Application of ionic liquids in microextraction techniques: current trends and future perspectives: current trends and future perspectives, Trac. Trends Anal. Chem. 119 (2019) 115614, doi:10.1016/j.trac.2019.07.025.
[45] X. Yin, H. Yi, Q. Wang, Y. Wang, X. Sun, C. Lv, J. Guo, Y. Yang, Extraction and separation of multiple platinum group metals from hydrochloric acid solution with sole 1-hexyl-3-methylimidazole-2-thione using microextraction method, Hydrometallurgy 174 (2017) 167-174, doi:10.1016/j.hydromet.2017.10.009.

[46] Y. Tong, C. Wang, Y. Huang, Y. Yang, Extraction and stripping of platinum from hydrochloric acid medium by mixed imidazolium ionic liquids, Ind. Eng. Chem. Res. 54 (2015) 705-711, doi:10.1021/ie503502g.

[47] R. Vlasankova, L. Sommer, Solid phase extraction and preconcentration for the determination of trace amounts of platinum group metals in environmental and biotic material - a critical review, Chem. Pap. Slovak Acad. Sci. 53 (1999) 200-209.

[48] J. Barakso, Determination of the Precious Metals: Selected Instrumental Methods: J.C. Van Loon and R.R. Barefoot. Wiley, New York, 1991, 276 pp, US\$ 115.00: Selected Instrumental Methods, J. Geochem. Explor. 43 (1992) 294-295, doi:10.1016/0375-6742(92)90114-N.

[49] M. Lee, G. Tölg, E. Beinrohr, P. Tschöpel, Preconcentration of palladium, platinum and rhodium by on-line sorbent extraction for graphite furnace atomic absorption spectrometry and inductively coupled plasma atomic emission spectrometry, Anal. Chim. Acta 272 (1993) 193-203, doi:10.1016/ 0003-2670(93)80569-7.

[50] M. Muzikar, C. Fontàs, M. Hidalgo, J. Havel, V. Salvadó, A preconcentration system using polyamine Metalfix-Chelamine resin for the on-line determination of palladium(II) and platinum(IV) by inductively coupled plasma optical emission spectrometry, Talanta 70 (2006) 1081-1086, doi:10.1016/ j.talanta.2006.02.021.

[51] M. Morcali, B. Zeytuncu, Investigation of adsorption parameters for platinum and palladium onto a modified polyacrylonitrile-based sorbent, Int. J. Miner. Process. 137 (2015) 52-58, doi:10.1016/j.minpro.2015.02.011.

[52] R. Komendova, J. Nevrla, J. Kuta, L. Sommer, Innovative preconcentration technique on polymer sorbent for simultaneous determination of platinum group metals in the waters and lichen Hypogymnia Physodes, Fresenius Environ. Bull. 25 (2016) 5172-5179 ISI://WOS:000391345600011.

[53] R. Vlasankova, V. Otruba, J. Bendl, M. Fisera, V. Kanicky, Preconcentration of platinum group metals on modified silicagel and their determination by inductively coupled plasma atomic emission spectrometry and inductively coupled plasma mass spectrometry in airborne particulates, Talanta 48 (1999) 839-846, doi:10.1016/S0039-9140(98)00100-3.

[54] R. Komendova-Vlasankova, L. Sommer, Separation and preconcentration of platinum group metals and gold on modified silica and XAD sorbents in the presence of cationic surfactants for their determination by ICP-AES, Collect. Czechoslov. Chem. Commun. 67 (2002) 454-470, doi:10.1135/cccc20020454.

[55] C. Bosch Ojeda, F. Sánchez Rojas, J. Cano Pavón, A. García de Torres, Automated on-line separation-preconcentration system for platinum determination by electrothermal atomic absorption spectrometry, Anal. Chim. Acta 494 (2003) 97-103, doi:10.1016/S0003-2670(03)01014-6.

[56] Ș. Tokalıoğlu, T. Oymak, Ș. Kartal, Determination of palladium in various samples by atomic absorption spectrometry after preconcentration with dimethylglyoxime on silica gel, Anal. Chim. Acta 511 (2004) 255-260, doi:10.1016/ j.aca.2004.02.015

[57] F. Rojas, C. Ojeda, J. Pavón, Automated on-line separation preconcentration system for palladium determination by graphite furnace atomic absorption spectrometry and its application to palladium determination in environmental and food samples, Talanta 70 (2006) 979-983, doi:10.1016/ j.talanta.2006.05.048.

[58] X. Wu, P. Liu, Q. Pu, Q. Sun, Z. Su, Preparation of dendrimer-like polyamidoamine immobilized silica gel and its application to online preconcentration and separation palladium prior to FAAS determination, Talanta 62 (2004) 918-923, doi:10.1016/j.talanta.2003.10.011.

[59] R. Sharma, A. Pandey, S. Gulati, A. Adholeya, An optimized procedure for preconcentration, determination and on-line recovery of palladium using highly selective diphenyldiketone-monothiosemicarbazone modified silica gel, J. Hazard Mater. 209-210 (2012) 285-292, doi:10.1016/j.jhazmat.2012.01.022.

[60] W. Nischkauer, M. Neouze, F. Vanhaecke, A. Limbeck, Extraction and pre-concentration of platinum and palladium from microwave-digested road dust via ion exchanging mesoporous silica microparticles prior to their quantification by 
quadrupole ICP-MS, Mikrochim. Acta 182 (2015) 2369-2376, doi:10.1007/ s00604-015-1643-0.

[61] M. Barczak, J. Dobrzyńska, M. Oszust, E. Skwarek, J. Ostrowski, E. Zięba, P. Borowski, R. Dobrowolski, Synthesis and application of thiolated mesoporous silicas for sorption, preconcentration and determination of platinum, Mater. Chem. Phys. 181 (2016) 126-135, doi:10.1016/j.matchemphys.2016.06.042.

[62] J. Dobrzyńska, R. Dobrowolski, R. Olchowski, E. Zięba, M. Barczak, Palladium adsorption and preconcentration onto thiol- and amine-functionalized mesoporous silicas with respect to analytical applications, Microporous Mesoporous Mater. 274 (2019) 127-137, doi:10.1016/j.micromeso.2018.07.038.

[63] R. Komendova, The HR-CS-GF-AAS determination and preconcentration of palladium in contaminated urban areas, especially in lichens, Environ. Pollut. (2019) 113468, doi:10.1016/j.envpol.2019.113468.

[64] R. Gaita, S. Al-Bazi, An ion-exchange method for selective separation of palladium, platinum and rhodium from solutions obtained by leaching automotive catalytic converters, Talanta 42 (1995) 249-255, doi:10.1016/ 0039-9140(94)00246-O.

[65] I. Jarvis, M. Totland, K. Jarvis, Assessment of Dowex 1-X8-based anion-exchange procedures for the separation and determination of ruthenium, rhodium, palladium, iridium, platinum and gold in geological samples by inductively coupled plasma mass spectrometry, Analyst 122 (1997) 19-26, doi:10.1039/a606169i.

[66] P. Kovacheva, R. Djingova, Ion-exchange method for separation and concentration of platinum and palladium for analysis of environmental samples by inductively coupled plasma atomic emission spectrometry, Anal. Chim. Acta 464 (2002) 7-13, doi:10.1016/S0003-2670(02)00428-2.

[67] M. González García, F. Sánchez Rojas, C. Bosch Ojeda, A. García de Torres, J. Cano Pavón, On-line ion-exchange preconcentration and determination of traces of platinum by electrothermal atomic absorption spectrometry, Anal. Bioanal. Chem. 375 (2003) 1229-1233, doi:10.1007/s00216-002-1679-y.

[68] N. Martos, P. Rudner, A. de Torres, J. Pavón, Development of an FI-ICP method for on-line preconcentration and determination of platinum, Microchimica Acta 148 (2004) 35-42, doi:10.1007/s00604-004-0256-9.

[69] P. Sun, J. Lee, M. Lee, Separation of platinum(IV) and rhodium(III) from acidic chloride solution by ion exchange with anion resins, Hydrometallurgy 113-114 (2012) 200-204, doi:10.1016/j.hydromet.2011.12.009.

[70] M. Alonso Castillo, A. García de Torres, E. Vereda Alonso, M. Siles Cordero, J. Cano Pavón, Multi-element determination of Pt, Pd and Ir traces in environmental samples by ICP-MS after pre-concentration, Talanta 99 (2012) 853-858, doi:10.1016/j.talanta.2012.07.042.

[71] A. Nikoloski, K. Ang, D. Li, Recovery of platinum, palladium and rhodium from acidic chloride leach solution using ion exchange resins, Hydrometallurgy 152 (2015) 20-32, doi:10.1016/j.hydromet.2014.12.006.

[72] A. Miroshnichenko, Sorption recovery of platinum metals from compound solutions, Procedia Eng. 152 (2016) 8-12, doi:10.1016/j.proeng.2016.07.607.

[73] S. Ježek, Stanovení Platinových Kovů Ve Velkých Městských Aglomeracích, Diplomová Práce, 2016.

[74] J. Sýkora, Využití Iontoměničů Pro Prekoncentraci Platinových Kovů, Diplomová práce, 2017.

[75] I. Jarvis, M. Totland, K. Jarvis, Determination of the platinum-group elements in geological materials by ICP-MS using microwave digestion, alkali fusion and cation-exchange chromatography, Chem. Geol. 143 (1997) 27-42, doi:10.1016 S0009-2541(97)00098-3.

[76] J. Whiteley, F. Murray, Anthropogenic platinum group element (Pt, Pd and Rh) concentrations in road dusts and roadside soils from Perth, Western Australia, Sci. Total Environ. 317 (2003) 121-135, doi:10.1016/S0048-9697(03)00359-0.

[77] J. Whiteley, F. Murray, Autocatalyst-derived platinum, palladium and rhodium (PGE) in infiltration basin and wetland sediments receiving urban runoff, Sci. Total Environ. 341 (2005) 199-209, doi:10.1016/j.scitotenv.2004.09.030.

[78] D. Afzali, R. Jamshidi, S. Ghaseminezhad, Z. Afzali, Preconcentration procedure trace amounts of palladium using modified multiwalled carbon nanotubes sor- bent prior to flame atomic absorption spectrometry: 1st Nano update, Arabian. J. Chem 5 (2012) 461-466, doi:10.1016/j.arabjc.2011.01.017.

[79] M. Taher, Z. Daliri, H. Fazelirad, Simultaneous extraction and preconcentration of copper, silver and palladium with modified alumina and their determination by electrothermal atomic absorption spectrometry, Chin. Chem. Lett. 25 (2014) 649-654, doi:10.1016/j.cclet.2013.12.025.

[80] H. Hong, H. Yu, M. Park, H. Jeong, Recovery of platinum from waste effluent using polyethyleneimine-modified nanocelluloses: effects of the cellulose source and type: effects of the cellulose source and type, Carbohydr. Polym. 210 (2019) 167-174, doi:10.1016/j.carbpol.2019.01.079.

[81] C. Wiseman, F. Zereini (Eds.), Platinum Metals in the Environment, 1 ed., Springer, Berlin, 2015.

[82] Cisplatina(n.d.)www.sukl.cz

[83] O. Šebek, M. Mihaljevič, L. Strnad, V. Ettler, J. Ježek, R. Štědrý, P. Drahota, L. Ackerman, V. Adamec, Dissolution kinetics of Pd and Pt from automobile catalysts by naturally occurring complexing agents, J. Hazard Mater. 198 (2011) 331-339, doi:10.1016/j.jhazmat.2011.10.051.

[84] F. Zereini, F. Alt (Eds.), Palladium Emissions in the Environment, 1 ed., Springer, Berlin, 2005.

[85] E. Kranjc, D. Mazej, M. Regvar, D. Drobne, M. Remškar, Foliar surface free energy affects platinum nanoparticle adhesion, uptake, and translocation from leaves to roots in arugula and escarole, Environ. Sci.: Nano 5 (2018) 520-532, doi:10.1039/C7EN00887B.

[86] R. Komendová, J. Žídek, M. Berka, M. Jemelková, V. Řezáčová, P. Conte, J. Kučerík, Small-sized platinum nanoparticles in soil organic matter: influence on water holding capacity, evaporation and structural rigidity: influence on water holding capacity, evaporation and structural rigidity, Sci. Total Environ. 694 (2019) 133822, doi:10.1016/j.scitotenv.2019.133822.

[87] R. Schierl, Environmental monitoring of platinum in air and urine, Microchem. J. 67 (2000) 245-248, doi:10.1016/S0026-265X(00)00068-0.

[88] M. Sharma, Platinum Group Elements and Their Isotopes in the Ocean, Academic Press, Oxford, 2019, pp. 174-180, doi:10.1016/ B978-0-12-409548-9.11556-8.

[89] D. López-Sánchez, A. Cobelo-García, M. Rijkenberg, L. Gerringa, H. de Baar, New insights on the dissolved platinum behavior in the Atlantic Ocean, Chem. Geol. 511 (2019) 204-211, doi:10.1016/j.chemgeo.2019.01.003.

[90] M. Abdou, J. Schäfer, A. Cobelo-García, P. Neira, J. Petit, D. Auger, J. Chiffoleau, G. Blanc, Past and present platinum contamination of a major European fluvial-estuarine system: insights from river sediments and estuarine oysters: insights from river sediments and estuarine oysters, Mar. Chem. 185 (2016) 104-110, doi:10.1016/j.marchem.2016.01.006.

[91] A. Cobelo-García, P. Neira, M. Mil-Homens, M. Caetano, Evaluation of the contamination of platinum in estuarine and coastal sediments (Tagus Estuary and Prodelta, Portugal), Mar. Pollut. Bull. 62 (2011) 646-650, doi:10.1016/ j.marpolbul.2010.12.018.

[92] M. Novotný, Studium Kontaminace Říčních Sedimentů Platinovými Kovy, Diplomová práce, 2018.

[93] C. Wiseman, Z. Hassan Pour, F. Zereini, Platinum group element and cerium concentrations in roadside environments in Toronto, Canada, Chemosphere 145 (2016) 61-67, doi:10.1016/j.chemosphere.2015.11.056.

[94] R. Ma, I. Staton, C. McLeod, M. Gomez, M. Gomez, M. Palacios, Assessment of airborne platinum contamination via ICP-mass spectrometric analysis of tree bark, J. Anal. At. Spectrom. 16 (2001) 1070-1075, doi:10.1039/b102940c.

[95] G. Rentschler, I. Rodushkin, M. Cerna, C. Chen, F. Harari, R. Harari, M. Horvat, F. Hruba, L. Kasparova, K. Koppova, A. Krskova, M. Krsnik, J. Laamech, Y. Li, L. Löfmark, T. Lundh, N. Lundström, B. Lyoussi, D. Mazej, J. Osredkar, K. Pawlas, N. Pawlas, A. Prokopowicz, S. Skerfving, J. Snoj Tratnik, V. Spevackova, Z. Spiric, A. Sundkvist, U. Strömberg, D. Vadla, K. Wranova, S. Zizi, I. Bergdahl, Platinum, palladium, rhodium, molybdenum and strontium in blood of urban women in nine countries, Int. J. Hyg Environ. Health 221 (2018) 223-230, doi:10.1016/j.ijheh.2017.10.017. 